\title{
Impact of correction of ischemic mitral valve on left ventricular reverse remodeling
}

\author{
A Nikolic, ${ }^{*}$ M Mirocevic \\ From 23rd World Congress of the World Society of Cardio-Thoracic Surgeons \\ Split, Croatia. 12-15 September 2013
}

\section{Background}

Chronic ischemic mitral regurgitation (IMR) is frequent complication of myocardial infarction. It is associated with high cardiovascular morbidity and mortality. We examined the effects of surgery of ischemic mitral valve on reverse remodeling of left ventricle, impact on functional state of patients after operation, assessment of early morbidity and mortality.

\section{Methods}

Coronary artery bypass grafting (CABG) and surgical correction of ischemic mitral valve were performed in 52 patients with coronary artery disease (CAD) and IMR and 52 patients with CAD and IMR underwent only CABG. In both groups they had moderate or severe mitral insufficiency. Serial transthoracic and transesophageal echocardiograms were performed before surgery, after 6 months and after 12 months to assess grade of MR, left ventricular and left atrial remodeling, left ventricle ejection fraction. Clinical follow up NYHA functional classification, survival, events were assessed after 1-year follow up. Statistical test used were Mann Whitney U test, student's t-test, c2 test.

\section{Results}

LV end-systolic dimension decreased from 49.0 to $41.3 \mathrm{~mm}$ in combined operation group and from 45.4 to $42.0 \mathrm{~mm}$ in only CABG patients at one year follow up. LV end-diastolic dimension decreased from 65.1 to $59.3 \mathrm{~mm}$ in patients with both CABG and mitral valve surgery and from 60.6 to $58.1 \mathrm{~mm}$ in patients with only CABG after 12 months. Reverse remodeling of left ventricle occurred more frequently in group of patients with combined surgery, $71.8 \%$ vs $41.5 \%$ in only CABG group. Ejection fraction

\footnotetext{
* Correspondence: nikolic@india.com

Department of Cardiac Surgery, Clinical Center of Montenegro, Podgorica, Montenegro
}

(c) 2013 Nikolic and Mirocevic; licensee BioMed Central Ltd. This is an Open Access article distributed under the terms of the Creative Commons Attribution License (http://creativecommons.org/licenses/by/2.0), which permits unrestricted use, distribution, and reproduction in any medium, provided the original work is properly cited. increased for $7.5 \%$ in combined group and $2.5 \%$ in only CABG group. NYHA class improved in both groups of patients, but with more significant result in combined operation group.

\section{Conclusion}

In patients with ischemic mitral valve better results of left ventricular reverse remodeling were obtained with combined CABG and mitral valve surgery than in patients without surgical correction of ischemic mitral valve.

Published: 11 September 2013

doi:10.1186/1749-8090-8-S1-O280

Cite this article as: Nikolic and Mirocevic: Impact of correction of ischemic mitral valve on left ventricular reverse remodeling. Journal of Cardiothoracic Surgery 2013 8(Suppl 1):O280.
Submit your next manuscript to BioMed Central and take full advantage of:

- Convenient online submission

- Thorough peer review

- No space constraints or color figure charges

- Immediate publication on acceptance

- Inclusion in PubMed, CAS, Scopus and Google Scholar

- Research which is freely available for redistribution
C Biomed Central 